\title{
MOTYWY DELOKALIZACJI CENTRÓW USŁUG OUTSOURCINGOWYCH DO MIAST W POLSCE
}

\section{WPROWADZENIE}

Sektor usług w gospodarce krajów świata wzrasta nadal. We wszystkich krajach Unii Europejskiej usługi stały się sektorem dominującym ${ }^{1}$, zarówno pod względem udziału w tworzeniu PKB, jak i zatrudnieniu, przekraczając 50\%. Wydajność pracy $\mathrm{w}$ tym sektorze jest najwyższa, a udział wytworzonej wartości dodanej brutto większy niż z innych sektorów. Usługi obejmuja działania sfery okołobiznesowej ułatwiającej wdrażanie innowacji oraz usługi wyższego rzędu związane $\mathrm{z}$ sektorem badawczo-rozwojowym ${ }^{2}$. W tym kontekście należy też zwrócić uwagę na postępująca globalizację gospodarcza, którą ułatwia ogromna redukcja kosztów w transporcie i telekomunikacji oraz znoszenie sztucznych barier w przepływach dóbr, usług, kapitału, wiedzy. Globalizacji towarzyszy tworzenie nowych instytucji, które obok już istniejących prowadzą działalność przekraczająca granice państw ${ }^{3}$. Warunki te sprzyjają rozwojowi usług biznesowych, które odgrywają ważną rolę w rozwoju społeczno-gospodarczym dużych miast początku XXI w. Poziomowi rozwoju usług w danej lokalizacji można przypisywać kluczowe znaczenie wśród czynników konkurencyjności miast.

Rynek usług biznesowych w ostatnich kilkunastu latach rozwija się bardzo dynamicznie. Dotyczy to zarówno świata, jak i Polski. Początkowo lokalizacją dla przenoszonych działalności usługowych były Indie. Zaistniałe tam zmiany uwarunkowań geopolitycznych i ekonomicznych spowodowały, że zainteresowanie zachodnich korporacji skierowało się także na trzy inne regiony świata: Azję Płd.-Wsch. (ChRL, Filipiny, Malezja, Wietnam), Amerykę Łacińską (Brazylia, Chile, Kostaryka, Meksyk) oraz kraje Europy Środkowo-Wschodniej. Nowoczesne usługi biznesowe sa obecnie wykonywane w ponad 100 państwach na świecie. Światowym liderem pozostaja nadal Indie (ok. $40 \%$ udział w rynku). Prognozy ${ }^{4}$ wskazuja, że w najbliższych latach udział tego państwa będzie się zmniejszać kosztem innych lokalizacji. Warto podkreślić, że w ostat-

\footnotetext{
${ }^{1} \mathrm{Z}$ wyjątkiem Rumunii.

2 M. Czerny, Geografia Unii Europejskiej, WN PWN, Warszawa 2008, s. 121.

${ }^{3}$ J. Stiglitz, Globalizacja, WN PWN, Warszawa 2004, s. 26.

${ }^{4}$ ABSL, Sektor nowoczesnych ustug biznesowych w Polsce 2015.
} 
nich kilku latach zaznaczył się wyraźny wzrost udziału Europy Środkowo-Wschodniej w globalnym rynku usług. Udział tego regionu, w którym liderem jest Polska, szacowany jest obecnie na około 7-8\% całkowitej wartości nowoczesnych usług biznesowych na świecie. Działa tu około 1000 centrów usług z kapitałem zagranicznym (stan na koniec 2013 r.). Zdecydowana większość z nich to inwestycje przedsiębiorstw z USA i krajów Europy Zachodniej.

Obserwowany proces przenoszenia części przedsiębiorstw jest związany z zaostrzająca się konkurencją na globalnym rynku. Sprawia ona, że przedsiębiorstwa poszukują nowych rozwiązań organizacyjnych i technologicznych, umożliwiajacych: zaspokajanie zmieniajacych się potrzeb i rosnących wymagań klientów; poprawę jakości wytwarzanych produktów i usług; podniesienie wydajności pracy oraz obniżenie kosztów. Joseph Stiglitz ${ }^{5}$ zwraca uwagę, że priorytetem przedsiębiorstwa jest zysk. Konsekwencją drogi do jego maksymalizacji jest więc obniżanie kosztów w każdy możliwy, prawem dozwolony sposób. Dotyczy to np. unikania płacenia podatków czy ograniczenie ubezpieczeń społecznych. Dlatego właśnie przedsiębiorstwa podejmuja decyzje o przeniesieniu działalności gospodarczej za granicę, defragmentując własny łańcuch wartości w skali globalnej. Zjawisko to wiąże się z dwoma charakterystycznymi tendencjami współczesnego zarządzania: delokalizacji i outsourcingu. Obie sprzyjają tworzeniu centrów nowoczesnych usług biznesowych.

Użyte w tytule opracowania słowo „motywy” oznacza tyle co czynniki, inaczej bodźce skłaniające jakiśs podmiot do działania, uzasadniające czyjąś decyzję. Należy je rozumieć jako czynniki lokalizacji, w tym przypadku jako czynniki delokalizacji. Czynniki lokalizacji traktowane sa jako wymogi i walory lokalizacyjne, odgrywaja $\mathrm{w}$ procesie lokalizacji podstawową rolę. $\mathrm{Z}$ jednej strony sa to wymagania stawiane przez inwestora, które powinny spełnić określone miejsca w celu zapewnienia odpowiednich korzyści. Z drugiej zaś - sa to walory użytkowe, czyli wszystkie wartości, które oferuje określone miejsce w celu najlepszego zaspokojenia potrzeb inwestora. Celem poznawczym podjętego $\mathrm{w}$ artykule badania jest identyfikacja i weryfikacja empiryczna czynników determinujących decyzje o lokalizacji podmiotów z udziałem kapitału zagranicznego świadczących usługi outsourcingowe na terenie Polski oraz określenie rangi ich istotności dla inwestorów.

Dla realizacji podjętego celu przeprowadzono w 2014 i 2015 r. badanie empiryczne z użyciem standaryzowanego wywiadu kwestionariuszowego skierowanego do menedżerów ${ }^{6}$ uczestniczacych w przygotowaniu procesu decyzyjnego wyboru lokalizacji centrum outsourcingowego na terenie Polski. Podmiot badania stanowiły przedsiębiorstwa z udziałem kapitału zagranicznego, które utworzyły centra outsourcingowe w 12 lokalizacjach: Warszawa, Kraków, Wrocław, Trójmiasto, Łódź, konurbacja śląska7, Poznań, Bydgoszcz,

${ }^{5}$ J. Stiglitz, Wizja sprawiedliwej globalizacji. Propozycje usprawnien, WN PWN, Warszawa 2007, s. 202.

${ }^{6}$ Byli to: właściciel, prezes, członek zespołu roboczego, uczestnik komitetu sterującego, doradca lub osoba przygotowująca proces ustalenia lokalizacji.

${ }^{7}$ Spośród 19 miast województwa ślaskiego tworzacych konurbację tylko Katowice maja znaczenie jako miejsce lokalizacji centrów usług outsourcingowych. W pozostałych miastach zlokalizowana jest sporadyczna liczba podmiotów rozpatrywanej branży. 
Szczecin, Lublin, Kielce i Bielsko-Biała. Spośród 325 inwestorów (niektórzy inwestorzy posiadaja więcej niż jedno centrum), wybrano celową próbę 30 respondentów, tj. niespełna 10\% ogółu inwestorów w okresie badania. Obszary działalności obsługiwane przez badane centra to: usługi finansowo-księgowe (35\%), obsługa klienta (17\%), kadry i płace (17\%), usługi IT (11\%), B\&R (7\%) i pozostałe (13\%). Badana grupa reprezentowała wszystkie typy centrów outsourcingowych z przewaga $\mathrm{SSC}^{8}(40 \%$ ogółu). Zasięg terytorialny obsługi centrów stanowiły kraje wysoko rozwinięte, w większości Europejskiego Obszaru Gospodarczego (62\%; zaledwie jedno przedsiębiorstwo obejmowało zasięgiem obsługi tylko Polskę). Można uznać, że przyjęta w badaniu próba była reprezentatywna. Uzupełnieniem analizy empirycznej pracy jest systematyzacja terminologiczna i typologia centrów usług outsourcingowych oraz analiza ilościowa ich aktualnego stanu i rozmieszczenia w Polsce.

\section{DELOKALIZACJA I OUTSOURCING - WSPÓLCZESNE TRENDY W ZARZĄDZANIU}

Aby zrozumieć zagadnienia nowych tendencji w przenoszeniu produkcji lub usług, należy odwołać się do jednego ze współczesnych trendów w zarządzaniu - delokalizacji ${ }^{9}$. Delokalizacja (określana też niekiedy jako relokacja) związana jest $\mathrm{z}$ dezintegracją procesu produkcyjnego lub świadczenia usług, której efektem jest przenoszenie elementów łańcucha wartości przedsiębiorstwa lub organizacji do miejsc często bardzo odległych. Tradycyjnie delokalizacja dotyczyła przenoszenia za granicę działalności produkcyjnej. Jednak upowszechnienie i niska cena rozwiązań telekomunikacyjnych pozwoliły również na delokalizacji usług. Tym procesom sprzyjają: wzrost kompetencji i umiejętności pracowników w krajach słabiej rozwiniętych oraz cyfryzacja wielu procesów biznesowych.

Przenoszenie procesu produkcyjnego (usług) za granicę ma na celu wykorzystanie przewag komparatywnych poszczególnych krajów. W przypadku relokacji, postrzeganej niekiedy jako przeniesienie pierwotnej lokalizacji przedsiębiorstwa w obrębie kraju, występuje substytucja jednego miejsca przez inne. Podmiot wykorzystuje tutaj swoje doświadczenie nabyte z dokonywanego wcześniej wyboru lokalizacji pierwotnej ${ }^{10}$. Pojęcie delokalizacji ${ }^{11}$ odnosi się zasadniczo do przypadku eksternalizacji zagranicznej i może przybrać dwie formy: delokalizacji sensu stricto (offshore-inhouse sourcing) i sensu largo (offshore outsourcing).

\footnotetext{
${ }^{8}$ Typologię centrów usług outsourcingowych przedstawiono w części III artykułu.

${ }^{9}$ Termin ten wprowadzony został niedawno - prawdopodobnie w 1996 r. przez E. Leamera, jako określenie sposobu fragmentacji produkcji; choć po raz pierwszy pojawił się już w $1961 \mathrm{r}$. w Webster's Dictionary.

${ }^{10}$ E. Małuszyńska, Migracje i delokalizacja przedsiębiorstw, Wyd. UE w Poznaniu, Poznań 2013, s. 32.

${ }^{11}$ OECD, Offshoring and Employment. Trends and Impacts, Danvers 2007, s. 15-16.
} 
Delokalizacja sensu stricto odbywa się wewnątrz firmy. W tym przypadku działalność produkcyjna jest całkowicie lub częściowo przenoszona za granicę $\mathrm{w}$ ramach tego samego przedsiębiorstwa lub tej samej grupy kapitałowo powiązanych przedsiębiorstw. Ten typ delokalizacji oznacza całkowite (lub częściowe) zaprzestanie działalności gospodarczej w kraju z jednoczesnym przeniesieniem tej samej działalności do już istniejącej lub specjalnie utworzonej filii zagranicznej. Ta forma delokalizacji dotyczy wyłącznie przedsiębiorstw wielonarodowych, dokonujących bezpośrednich inwestycji zagranicznych.

Z kolei delokalizacja sensu largo oznacza przeniesienie częściowe (lub całkowite) działalności produkcyjnej za granicę do przedsiębiorstwa niepowiązanego kapitałowo. Ta operacja odnosi się zatem do korzystania z podwykonawstwa zagranicznego. Podwykonawca ten może być kontrolowany zarówno przez rezydenta kraju, w którym podwykonawca funkcjonuje, jak i przez rezydenta zagranicznego lub inne przedsiębiorstwo pochodzące z kraju, z którego działalność jest delokalizowana. Ten rodzaj delokalizacji odbywa się za pośrednictwem przedsiębiorstwa niepowiązanego kapitałowo.

Druga ze współczesnych tendencji w zarządzaniu to outsourcing ${ }^{12}$. Jest to po prostu wydzielanie ze struktur organizacyjnych przedsiębiorstw niektórych realizowanych przez nie samodzielnie funkcji i przekazanie ich do wykonania innym podmiotom ${ }^{13}$. Koncepcja outsourcingu w biznesie znana jest od lat dwudziestych XX w. Termin ten po raz pierwszy został użyty w 1979 r. i odnosił się do kupowania niemieckich projektów przez brytyjski przemysł motoryzacyjny. Outsourcing w latach osiemdziesiątych oznaczał przede wszystkim zamawianie przez przedsiębiorstwo półproduktów i podzespołów za granica. W latach dziewięćdziesiątych w ten sposób nazywano wykonywanie określonych usług w przedsiębiorstwach zagranicznych.

Usługi outsourcingowe znajdują najczęściej zastosowanie w następujących obszarach działalności przedsiębiorstw: a) usługi: księgowe i finansowo-analityczne, IT, call center szkoleniowe, transportowe, ochrony mienia, marketingowe; b) zarządzanie: projektami w zakresie controllingu, jakościa, projektami $\mathrm{w}$ zakresie restrukturyzacji lub reorganizacji, projektami w zakresie informacji zarządczej, personelem, oraz c) administracja.

Celem outsourcingu w ujęciu ogólnym jest zwiększenie skuteczności i efektywności prowadzonej działalności. Zgodnie z koncepcją kluczowych kompetencji (ang. core competencies) chodzi o to, by przedsiębiorstwo skoncentrowało się na rozwijaniu czynności i procesów, które stanowią o jego wyjątkowości - decydujących o jego pozycji konkurencyjnej i perspektywach rozwojowych. Z kolei mniej istotne czynności, jeżeli moga być wykonane lepiej lub taniej, mogą być zlecane innym firmom. Prowadzić powinno to do lepszej realizacji celów ekonomicznych: zwiększenia przychodów, redukcji kosztów, a co za tym idzie - poprawy wyników ekonomicznych i ograniczenia ryzyka ekonomicznego prowadzonej działalności. W wyniku outsourcingu następuje redukcja struktury organizacyjnej zakładu macierzystego, a w ślad za tym - uproszczenie struktur i procedur organizacyjnych skutkujące poprawą zarządzania.

12 Nazwa jest akronimem wyrażenia outside-recource-using, co w dosłownym tłumaczeniu oznacza korzystanie z zasobów zewnętrznych.

13 M. Trocki, Outsourcing, PWE, Warszawa 2001, s. 13. 


\section{TYPY CENTRÓW USŁUG OUTSOURCINGOWYCH}

Wspomniane wcześniej tendencje w zarządzaniu wraz z rozwojem nowych technologii przyczyniły się do powstania różnych kategorii ośrodków koncentrujących usługi outsourcingowe. Ze względu na tryb funkcjonowania względem zleceniodawców można je podzielić na trzy typy.

1. Centra usług wspólnych (shared service centre - SSC) - centra świadczące usługi na rzecz własnych przedsiębiorstw (powiązanych kapitałowo i strukturalnie). Polegaja ona na optymalizowaniu przez przedsiębiorstwo wewnętrznych procesów przez konsolidowanie w jednej lokalizacji czynności prowadzonych wcześniej w wielu oddziałach.

SSC jako organizacyjna koncepcja posiada następujące atrybuty ${ }^{14}$ :

- konsolidacja procesów w grupie kapitałowej w celu zmniejszenia zatrudnienia;

- dostarczanie procesów wsparcia dla głównego procesu biznesowego;

- jest odrębna jednostka organizacyjna w ramach grupy kapitałowej;

- jest porównywana z klientem zewnętrznym;

- redukcja kosztów jest głównym motorem wdrożenia tego rozwiązania organizacyjnego;

- obsługuje, skupia się na klientach wewnętrznych, podmiotach w grupie kapitałowej.

- działa jako niezależny podmiot.

Ten model usług opisywany jest często jako model systemu rynkowego. Podmioty dostawcy i klienta wchodza w związek partnerski przez umowę o świadczenie usług na zasadach wolnorynkowych. Pewną specyfiką usług w SSC jest to, że sa one „oddziałami” swoich grup kapitałowych. Korporacje takie zatrudniają bardzo często od kilku do kilkudziesięciu tysięcy pracowników. W takich przedsiębiorstwach wiedza know-how powstaje jako efekt doświadczenia, prób laboratoryjnych i technologicznych lub jako wynik spotkań i współpracy z dostawcami oraz odbiorcami danego przedsiębiorstwa.

2. Business process outsourcing (BPO) - centra dostarczające usługi dla klientów zewnętrznych. Tego typu centrum zajmuje się obsługa procesów biznesowych, administruje nimi, usprawnia je dla zewnętrznych odbiorców usług. Zachowuje przy tym uzgodnione z klientem standardy jakościowo-ilościowe wykonania tych usług. W odróżnieniu od SSC w tym typie centrum nie ma powiązań kapitałowych pomiędzy podmiotami zlecającymi i realizującymi zadania.

3. Knowledge process outsourcing (KPO) - to typ centrum usług, które można określić, jako takie, które bardziej jakościowo niż ilościowo opracowuje dostarczane dane. Sama nazwa sugeruje, że podejście do outsourcingu bazuje tutaj na wiedzy. KPO angażuje wyższej klasy analityków i analizy w celu dostarczenia organizacjom strategicznych i taktycznych narzędzi do podejmowania decyzji. Należy zaznaczyć, że zewnętrznymi zleceniobior-

${ }^{14}$ V. Schulz et al., Categorization of Shared Service Centers: Insights from the IT Services Industry, https://www.alexandria.unisg.ch/export/DL/223828.pdf [dostęp: 12.08.2015]. 
cami procesów są w tym przypadku ośrodki wyspecjalizowane w precyzyjnie określonym obszarze działania. Podstawowym celem nie jest jednak w tym przypadku oferowanie klientom oszczędności, lecz wysoka wartość dodana tworzona dla przedsiębiorstw ${ }^{15}$. Przykładami aplikacji tej koncepcji sa m.in.: analizy finansowe, badania rynku, badania i rozwój w przemyśle maszynowym, lotniczym czy farmaceutycznym, jak również obsługa prawna.

Warto dodać, że niektóre centra obsługują zarówno firmę macierzysta, jak i klientów z rynku, świadcząc usługę komercyjną. Ten model działalności biznesowej nazywamy hybrydowym model świadczenia usług. W tabeli 1 przedstawiono interpretacje relacji pomiędzy centrami usług outsourcingowych a klientami. Uwzględnia ona powiązania kapitałowe oraz charakter współpracy. W przypadku spółek KPO świadczą one usługi dla podmiotów powiązanych lub niepowiązanych kapitałowo. Mogą one świadczyć również usługi w tym samym czasie dla innych podmiotów, które są powiązane i niepowiązane z nimi kapitałowo.

\section{Tabela 1}

Typy centrów outsourcingowych ze względu na tryb funkcjonowania względem zleceniodawców oraz powiazania kapitałowe stron

\begin{tabular}{|l|c|c|}
\hline \multirow{2}{*}{ Rodzaj usługi } & \multicolumn{2}{|c|}{$\begin{array}{c}\text { Powiązania kapitałowe między klientem } \\
\text { a dostawcą usług }\end{array}$} \\
\cline { 2 - 3 } & Tak & Nie \\
\hline Obsługa procesów biznesowych & SSC & BPO \\
\hline $\begin{array}{l}\text { Przetwarzanie i dostarczanie } \\
\text { wysokiej jakości informacji }\end{array}$ & KPO & KPO \\
\hline
\end{tabular}

Źródło: opracowanie własne.

\section{OUTSOURCING PROCESÓW BIZNESOWYCH W POLSCE}

Pierwsze centra usług pojawiły się w Polsce już w latach dziewięćdziesiątych, jednakże wyraźny wzrost napływu inwestycji z sektora nowoczesnych usług biznesowych nastapił po wstapieniu Polski do Unii Europejskiej. Przyczyniło się to do wzrostu wiarygodności politycznej kraju oraz zmian w zakresie uwarunkowań prawnych funkcjonowania działalności gospodarczej i wpłynęło na pozytywną reakcję inwestorów. Stąd blisko 85\% centrów działających w Polsce powstało po 2004 r. (wykres 1). Decydujące znaczenie w kontekście boomu inwestycyjnego miał jednak rozwój sektora w skali globalnej i związana z tym konieczność poszukiwania nowych rynków spełniających zapotrzebowanie na świadczenie nowoczesnych usług biznesowych. Ważnym czynnikiem

${ }_{15}$ A. Mierau, Strategic Importance of Knowledge Process Outsourcing, Technical University of Kaiserslautern 2007, s. 20. 
rozwoju tego typu usług okazał się również kryzys. Wiele międzynarodowych korporacji, poszukując oszczędności, zaczęło przekazywać wybrane procesy biznesowe firmom zewnętrznym lub tworzyć własne jednostki outsourcingowe. Impulsem do rozwoju jest też postępująca specjalizacja w ramach coraz bardziej złożonych procesów biznesowych.

Efektem wskazanych czynników są powstałe w Polsce 532 centra usług z kapitałem zagranicznym (stan: maj 2015 r.). Ich liczba nadal wzrasta (wykres 1). Można zakładać, że w 2016 r. liczba centrów z kapitałem zagranicznym w Polsce wzrośnie do ponad $600^{16}$.

\section{Wykres 1}

Liczba centrów usług outsourcingowych z kapitałem zagranicznym w Polsce (*prognoza)

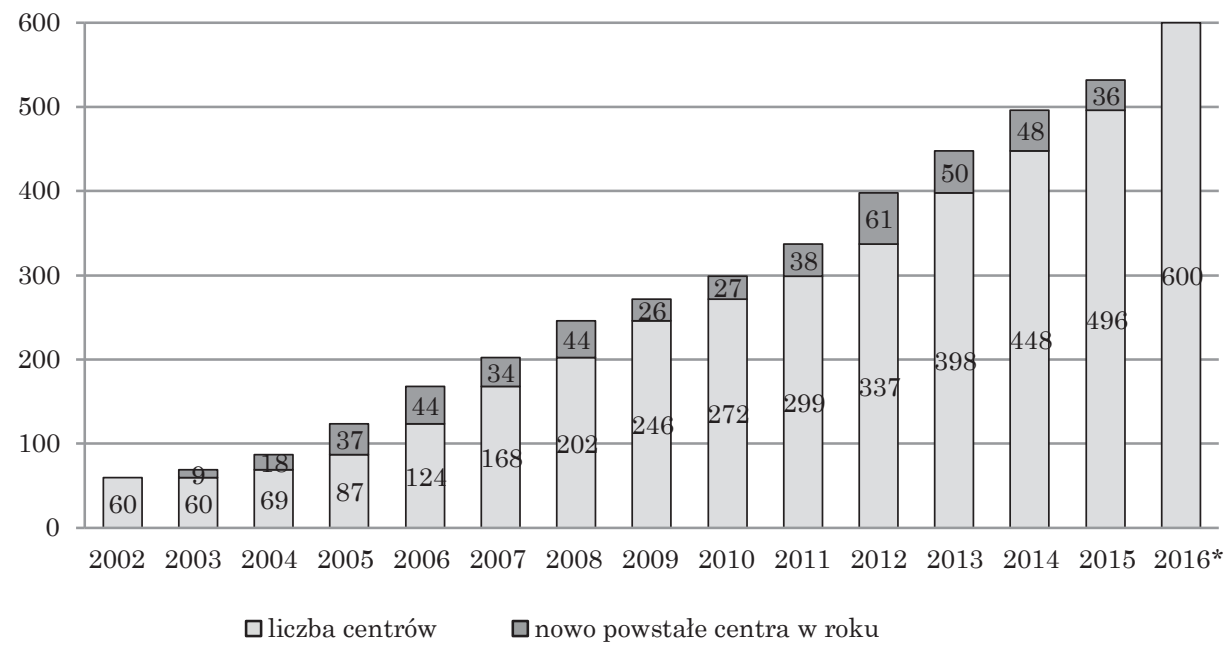

Źródło: na podstawie J. Górecki, Charakterystyka sektora nowoczesnych ustug biznesowych w Polsce, w: Sektor nowoczesnych ustug biznesowych $w$ Polsce 2014, ZLSUB w Polsce, Warszawa 2014, s. 14; ABSL, Sektor nowoczesnych ustug biznesowych $w$ Polsce 2015.

Polska jest obecnie w Europie Środkowo-Wschodniej liderem branży usług outsourcingowych. W całym regionie znajduje się 21 najważniejszych ośrodków offshoringu usług. Polska wyróżnia się na tle Europy Środkowo-Wschodniej dużą liczbą i przestrzennym rozproszeniem takich ośrodków. Niektóre z miast zdobywają silną pozycję w kategorii ośrodków offshoringu usług. W corocznym rankingu atrakcyjności miast - liderów światowego outsourcingu według Tholons znalazły się 3 polskie miasta, których pozycja corocznie się wzmacnia (tab. 2). Kraków zają ponownie bardzo wysoką 9 pozycję wśród najbardziej atrakcyjnych 100 lokalizacji dla outsourcingu usług biznesowych na świecie!

${ }^{16}$ ABSL, op. cit. 


\section{Tabela 2}

Pozycje polskich miast $\mathrm{w}$ rankingu światowego outsourcingu (w nawiasie zmiana pozycji)

\begin{tabular}{|l|c|c|c|c|c|}
\hline \multirow{2}{*}{\multicolumn{1}{|c|}{ Miasta }} & \multicolumn{5}{|c|}{ Lata } \\
\cline { 2 - 6 } & $\mathbf{2 0 1 1}$ & $\mathbf{2 0 1 2}$ & $\mathbf{2 0 1 3}$ & $\mathbf{2 0 1 4}$ & $\mathbf{2 0 1 5}$ \\
\hline Kraków & 11 & $11(-)$ & $10(+1 \uparrow)$ & $9(+1 \uparrow)$ & $9(-)$ \\
\hline Warszawa & 38 & $38(-)$ & $36(+2 \uparrow)$ & $32(+4 \uparrow)$ & $30(+2 \uparrow)$ \\
\hline Wrocław & 84 & $78(+6 \uparrow)$ & $75(+3 \uparrow)$ & $65(+10 \uparrow)$ & $62(+3 \uparrow)$ \\
\hline
\end{tabular}

Źródło: opracowanie na podstawie http://www.tholons.com/TholonsTop100 [dostęp: 30.09.2015].

Dowodem silnej pozycji Polski jest też najwyższy poziom i wysoka dynamika zatrudnienia w branży. Do 150 tys. osób zatrudnionych w 2015 r. w centrach z kapitałem zagranicznym należy dodać kilkanaście tysięcy pracowników zatrudnionych w firmach z kapitałem wyłącznie polskim. Tylko w okresie ostatnich dwóch lat (2013-2015) liczba pracowników centrów usług z kapitałem zagranicznym zwiększyła się o ponad 1/3. Biorąc pod uwagę dotychczasowy rozwój branży, można szacować, że w 2020 r. zagraniczne centra usług biznesowych w Polsce mogą zatrudniać nawet 250 tys. osób.

\section{Wykres 2}

Zatrudnienie w centrach usług outsourcingowych z kapitałem zagranicznym w Polsce (*prognoza)

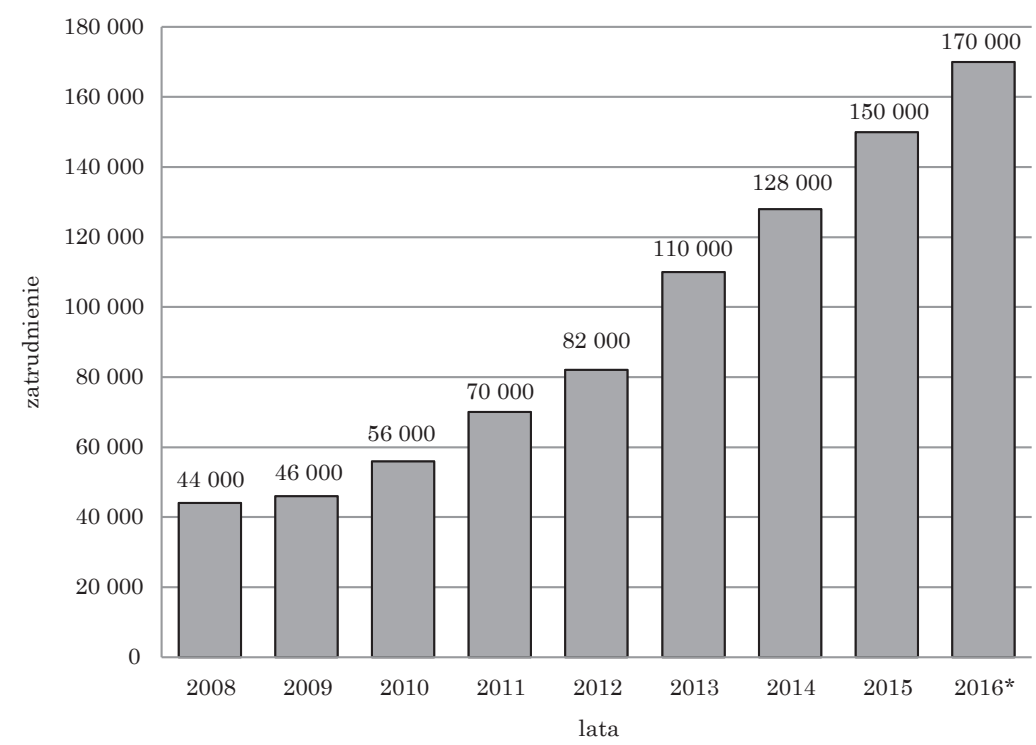

Źródło: na podstawie J. Górecki, Charakterystyka sektora nowoczesnych ustug biznesowych w Polsce, w: Sektor nowoczesnych ustug biznesowych w Polsce 2014, ZLSUB w Polsce, Warszawa 2014, s. 11; ABSL, Sektor nowoczesnych ustug biznesowych w Polsce 2015. 
Firmy z sektora obsługują szeroki wachlarz procesów dla klientów z całego świata reprezentujących różnorodne branże. Struktura usług świadczonych w centrach w Polsce charakteryzuje się zróżnicowaniem. Dominują w niej trzy procesy biznesowe. Są to: finanse i księgowość (17,9\% centrów), usługi IT (17,7\%) oraz działalność BiR (17,6\%), realizowana nie tylko w centrach KPO, ale również w niektórych jednostkach świadczących bardziej zaawansowane usługi outsourcingu IT. W blisko 15\% centrów realizuje się procesy związane z obsługą klienta, a 10,8\% centrów zajmuje się zarządzaniem zasobami ludzkimi. Pełną strukturę usług przedstawia wykres 3. Jest ona dość ustabilizowana. Należy podkreślić, że zdecydowana większość centrów świadczy usługi w zakresie co najmniej dwóch procesów biznesowych (np. finansów i księgowości oraz usług IT). Stanowi to przejaw rosnącej kompleksowości działalności centrów w Polsce. Z drugiej strony na rynku wyróżniają się wyspecjalizowane centra, obsługujące najczęściej bardziej zaawansowane procesy.

\section{Wykres 3}

Struktura usług świadczonych w zagranicznych centrach usług outsourcingowych w Polsce w 2011 r. (w \%)

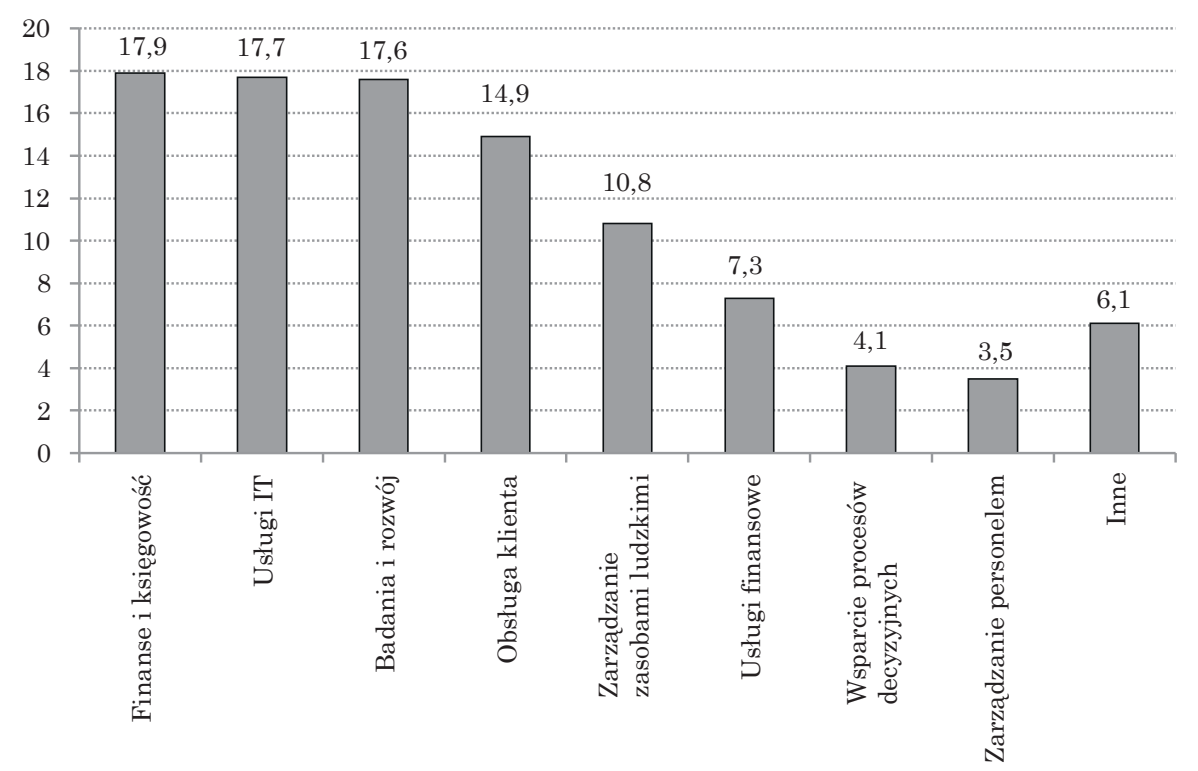

Źródło: na podstawie Sektor nowoczesnych ustug biznesowych w Polsce, ZLSUB w Polsce, Warszawa 2012 .

Cechą wyróżniającą Polskę na tle innych państw jest duża liczba bardzo dobrze rozwiniętych ośrodków miejskich, w których głównie zlokalizowane sa centra. Jest to przede wszystkim 7 ośrodków, w których mieści się 85\% wszystkich centrów usług. Są to: Kraków (101), Warszawa (93), Wrocław (67), Trójmiasto (56), Łódź (49), konurbacja ślaska (45) i Poznań (40). Liczbie funkcjo- 
nujących centrów usług odpowiada wielkość zatrudnienia. Najważniejszymi ośrodkami usług outsourcingowych pod tym względem są 3 miasta: Kraków (35, 7 tys. zatrudnionych), Warszawa (27,0 tys.) i Wrocław (23,7 tys.). W tych lokalizacjach pracuje łącznie 58\% ogółu zatrudnionych w centrach usług. Inne ważne skupiska centrów usług to: Trójmiasto (13,7 tys.), Łódź (13,1 tys.), konurbacja śląska (11,2 tys.) i Poznań $(9,0 \text { tys. })^{17}$. We wszystkich wyszczególnionych wyżej ośrodkach pracuje łącznie blisko $90 \%$ ogółu zatrudnionych w centrach usług z kapitałem zagranicznym w Polsce. Generalnie udział najważniejszych ośrodków usług dla biznesu w strukturze zatrudnienia sektora nie zmieniał się znacząco w ostatnich latach.

\section{DECYZJE INWESTORÓW ZAGRANICZNYCH O WYBORZE MIEJSCA CENTRUM OUTSOURCINGOWEGO}

Dynamicznie rozwijający się sektor usług outsourcingowych od początku budzi żywe zainteresowanie nie tylko rządów państw, ale również władz lokalnych - którym zależy na przyciagnięciu na swój obszar inwestycji i stworzeniu nowych miejsc pracy. Branża stała się również swoistym motorem napędzającym popyt na nowoczesne powierzchnie biurowe. Nie dziwi więc, że stała się ona obiektem zainteresowania społeczności lokalnych. Jednostki samorządu terytorialnego (JST) upatrują w niej jedno z kół zamachowych dla lokalnej gospodarki, i to w jej najbardziej pożądanej formie, czyli gospodarce opartej na wiedzy. Jednocześnie zainteresowane przyciaganiem inwestorów, którzy otwierają swoje centra usług outsourcingowych, jest lokalne otoczenie biznesu. Deweloperzy budujący na wynajem nowoczesne powierzchnie biurowe czy podmioty dostarczające usługi wsparcia biznesu (np. informatyczne, dostawy materiałów biurowych, transportu osób) zainteresowane są zwiększeniem swojego dotychczasowego udziału w rynku bez geograficznej ekspansji. Dlatego warto znaleźć odpowiedź na pytanie, jakie czynniki decydują o wyborze danej lokalizacji. Innymi słowy, czym kieruja się inwestorzy - podmioty z udziałem kapitału zagranicznego, którzy jako miejsce prowadzenia działalności usług outsourcingowych wybrali konkretne miasta Polski?

Aby przyciagnać wymagającego zagranicznego inwestora do miasta, trzeba wykazać się nie tylko dobrym położeniem i wynikająca z niego rentą lokalizacyjną. Miasto musi wyróżniać się zestawem ważnych czynników lokalizacyjnych. Można je podzielić na dwie grupy - twardych i miękkich. Czynniki twarde należy określić jako dość łatwo mierzalne i silnie związane z prowadzoną przez przedsiębiorstwo działalnością. Z kolei czynniki miękkie trudniej zmierzyć (lub oszacować) i nie są one związane bezpośrednio z działalnościa inwestora. Do wywiadu kwestionariuszowego przygotowano listę potencjalnych czynników lokalizacyjnych oferowanych przez dane miasto, które wpłynęły na decyzję inwestora. Została ona przygotowana w sposób dedukcyjny, na podstawie analizy literaturowej oraz dotychczasowych doświadczeń autorów

${ }^{17}$ Dane wg: ABSL, Sektor nowoczesnych ustug biznesowych w Polsce 2015. 
i zawierała 24 pozycje: 11 z nich określono jako czynniki miękkie, pozostałe 13 to czynniki twarde. Zadaniem respondentów było dokonanie oceny istotności tych czynników przez określenie siły wpływu na decyzję lokalizacyjną podmiotu. Skala ocen jest następująca: 1 - czynnik „nieważny” dla procesu decyzyjnego; 2 - „raczej nieważny”; 3 - „obojętny”; 4 - „raczej ważny”; 5 - „bardzo ważny”. Opinie respondentów z przeprowadzonych wywiadów potwierdzaja poprawność wszystkich czynników uwzględnionych w badaniu, choć ich istotność jest bardzo zróżnicowana. Wyniki analizy wpływu czynników na decyzję lokalizacyjna podmiotu przedstawia wykres 4 .

\section{Wykres 4}

\section{Ranking czynników}

wpływających na decyzję o lokalizacji centrum outsourcingowego w Polsce

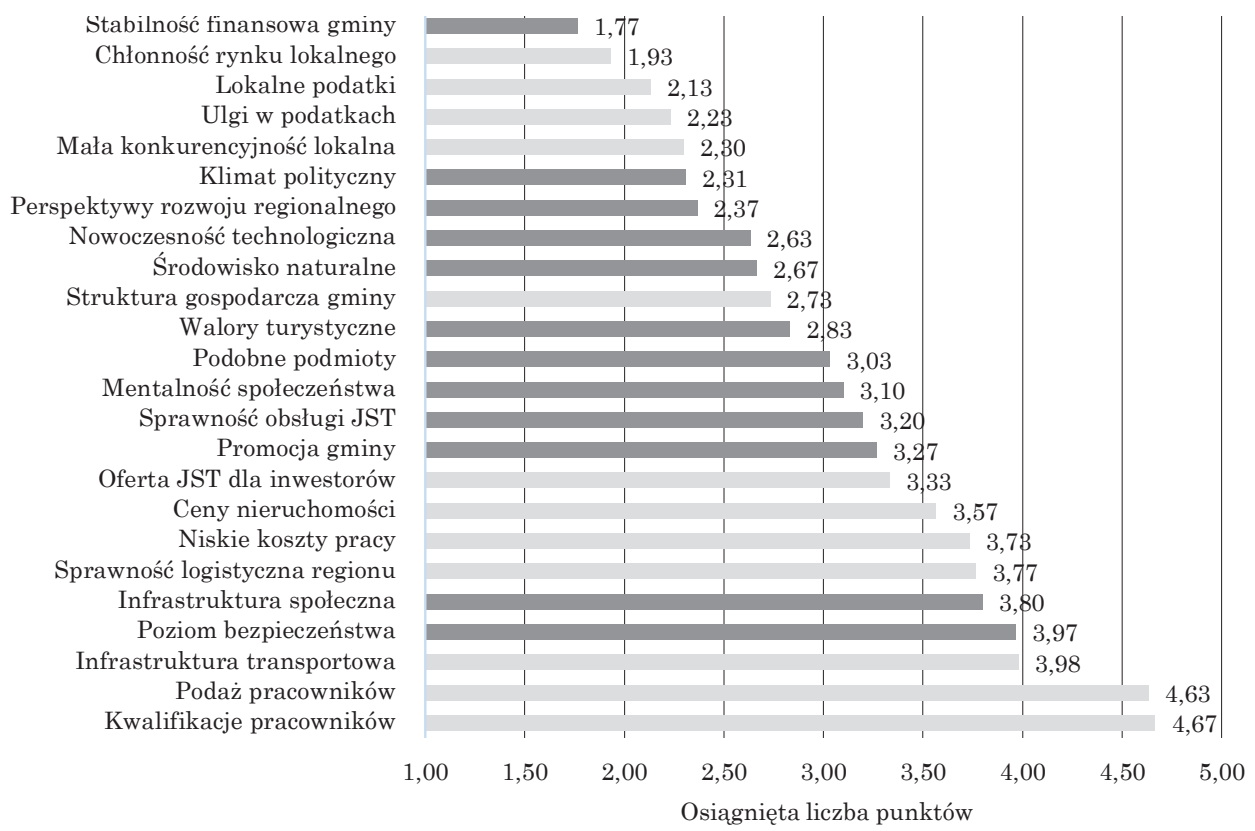

Kolor ciemny - czynniki miękkie, kolor jasny - czynniki twarde

Biorąc za kryterium istotności średnią ocen - powyżej 3, należy uznać taki czynnik za nieobojętny dla decyzji lokalizacyjnej. Można zatem stwierdzić, że 13 czynników tworzy listę istotnych motywów delokalizacji centrów usług outsourcingowych do polskich miast: 7 spośród nich to czynniki twarde, pozostałe 6 to miękkie. Dwa pierwsze, w opinii respondentów, sa zdecydowanie najważniejsze; to kwalifikacje i podaż pracowników. Co znamienne, uznawany do niedawna za podstawowy motyw outsourcingu i delokalizacji - obniżanie kosztów (w tym przede wszystkim kosztów pracy) znalazł się dopiero na siódmym miejscu. 
Najistotniejszy czynnik brany pod uwagę przy wyborze lokalizacji centrum to kwalifikacje kadry pracowniczej (4,67 pkt). Przyczyn takiego stanu jest kilka. Centra usług świadcza specjalistyczne usługi oparte na wiedzy. Prowadzenie lub wsparcie procesów: księgowych, kadrowych, zakupowych, informatycznych itp. wymaga określonej wiedzy. Często np. prowadzenie ksiag rachunkowych podmiotu wymaga znajomości prawa podatkowego kraju, w którym ma on siedzibę. Zakupy dla grup kapitałowych wymagaja specjalistycznej wiedzy kupca na temat rynków czy produktów. Obsługa procesów informacyjnych grup kapitałowych oparta jest często na bardzo dobrej znajomości zagadnienia całej grupy informatyków. Oprócz wiedzy teoretycznej osoby zatrudnione $\mathrm{w}$ centrach, mając kontakt $\mathrm{z}$ klientami na całym świecie, musza przede wszystkim się z nimi komunikować. Komunikacja odbywa się albo w języku narodowym klienta, albo w uznanym języku regionu geograficznego, w jakim klient operuje - np. angielskim. Stąd umiejętności lingwistyczne kadry pracowników są warunkiem obowiązkowym zatrudnienia. Średnia wieku osób zatrudnionych w takich centrach wynosi 29 lat, a 90\% wszystkich zatrudnionych ma wykształcenie wyższe ${ }^{18}$. Ten mariaż wykształcenia, wieku i oczekiwań inwestorów ma silne powiązanie z ośrodkami edukacji, skąd kadra pracownicza najchętniej jest pozyskiwana.

Drugi pod względem istotności czynnik lokalizacyjny - poda ż siły roboczej (4,63 pkt) jest związany, tak jak poprzedni, z możliwością pozyskania w danym mieście kadry pracowniczej. Oprócz tego, że pracownicy muszą mieć odpowiednie kwalifikacje, musi jeszcze ich być dostatecznie dużo. Centra $\mathrm{z}$ jednej strony specjalizują się $\mathrm{w}$ danej dziedzinie, $\mathrm{z}$ drugiej - obsługując duże grupy kapitałowe, potrzebują wielu specjalistów. Przeciętne centrum usług z kapitałem zagranicznym objętych próbą badawczą zatrudnia 320 osób. Do decyzji o posadowieniu takiego centrum osobom zarządzającym potrzebne sa gwarancje, że po kilku latach od jego otwarcia będzie można nadal rekrutować nowych pracowników.

Waga kolejnych sześciu czynników jest już mniejsza, choć nadal istotna dla procesu decyzyjnego. Infrastruktura transportowa (3,98 pkt) jest związana głównie z możliwością przemieszczania się do klientów i pomiędzy spółkami grup kapitałowych. Wprawdzie centra usług w codziennej pracy opieraja się na nowoczesnych narzędziach technologii przesyłu danych, ale docenia się wartość bezpośrednich kontaktów międzyludzkich. Nawiązanie współpracy, podsumowanie okresów pracy, kluczowe terminy projektu itp. wymagaja takich relacji. W przypadku kiedy obsługiwani klienci rozsiani sa po terenie np. całej Europy, zadaniem jest dotarcie do nich w jak najkrótszym czasie, gdyż wpływa to na koszty ich obsługi. Wszystkie miasta z pierwszej dziesiątki mają lotniska. Istotna dla inwestorów jest również sieć połączeń kolejowych i drogowych, ze szczególnym uwzględnieniem czasu dotarcia do Warszawy. Centralizacja w stolicy urzędów i instytucji istotnych w prowadzeniu biznesu sprawia, że reprezentanci podmiotów zwracają uwagę na to, aby był on jak najkrótszy. Według respondentów inwestorzy szukaja takiej lokalizacji, aby czas dojazdu z domu do pracy (door to door) nie przekraczał 50 minut. Oczy-

18 J. Górecki, op. cit., s. 27. 
wiście te uwarunkowania nie są związane wyłącznie z omawianym czynnikiem, ale również z „dostępnością i sprawnością logistyczną regionu” (czynnik numer sześć - 3,77 pkt). Również transport kolejowy jest analizowany w kontekście sprawności tego czynnika. Brana jest pod uwagę np. szybkość połączenia z miasta, w którym prowadzona jest działalność gospodarcza, do stolicy. Remonty trakcji kolejowej, wprowadzanie nowoczesnych składów „ocieplają” wizerunek miasta, w którym te działania zostały zrealizowane.

Kolejne na skali istotności dwa czynniki należą do grupy miękkich czynników. Pierwszy z nich - poziom bezpieczeństwa powszechnego w regionie (3,97 pkt) można rozpatrywać w dwóch wymiarach: bezpieczeństwa całego kraju/regionu oraz bezpieczeństwa na danym mieście. Istotność pierwszego obszaru ma znaczenie dla inwestorów na pierwszym etapie podejmowania decyzji (o wyborze kraju docelowego). Polska ma opinię bezpiecznego kraju, w którym nie ma zagrożenia stabilności dla biznesu. W wywiadach koncentrowano się na postrzeganiu wymiaru bezpieczeństwa powszechnego miasta, rozumianego jako ogół warunków i instytucji chroniących nie tylko życie i zdrowie obywateli, ale również ich mienie. Bezpieczeństwo publiczne rozumiane jest także jako szereg działań podejmowanych w zakresie zapewnienia ładu prawnego, jak również ochrony obywateli przed zjawiskami mogącymi zakłócić normalne funkcjonowanie.

Infrastruktura społeczna ( 3,80 pkt) to czynnik postrzegany jako otoczenie prowadzonego biznesu. Jednak dla inwestorów centrów usług outsourcingowych, którzy są bardzo świadomymi pracodawcami, istotny w biznesie. Bardzo ważny jest poziom szkolnictwa jako źródło aktualnych i przyszłych zasobów kadrowych. Inne elementy kształtują jakość życia, która przekłada się na zadowolenie i efektywność pracy.

Sklasyfikowane dopiero na siódmym miejscu koszty pracy (3,73 pkt) to teoretycznie podstawowy czynnik w procesie delokalizacji. Wszak tworzenie centrum ma na celu głównie obniżenie kosztów działalności podmiotów. Wynagrodzenia są tam w większości główną pozycją w rodzajowym ujęciu rachunku kosztów. Jednak już samo utworzenie takiego podmiotu w strukturze przez centralizację procesów, a w konsekwencji redukcję etatów daje oszczędności dla grupy kapitałowej. Średni poziom wynagrodzenia w poszczególnych miastach jest analizowany przez potencjalnych inwestorów. Sytuacja w tej sferze się zmienia. Obecnie, biorąc pod uwagę wynagrodzenie w poszczególnych grupach zawodowych (informatycy, księgowi, kadrowi itp.), również się różni. Czynnik ten ma bardziej znaczenie informacyjne niż determinujace lokalizację. Dynamiczny rozwój centrów w danej lokalizacji prowadzi do „wysysania” oraz „podkupywania” pracowników przez centra o podobnym profilu działalności. To w konsekwencji w dłuższym czasie powodować może zwiększenie poziomu wynagrodzenia w danej miejscowości. Pracownicy centrów ze względu na swoją specjalizację, oczekiwany poziom wynagrodzeń, mentalność stają się osobami, które w poszukiwaniu pracy migrują do innych miast.

Ceny nieruchomości oraz ich wynajmu i dzierżawy są ważnym „twardym" czynnikiem lokalizacji (3,57 pkt) branym pod uwage na etapie wyboru lokalizacji wariantów spełniających wybrane kryteria. Cecha ta jest silnie związana $\mathrm{z}$ dostępnością powierzchni biurowych oferowanych $\mathrm{w}$ nowoczes- 
nych budynkach o standardzie A (wyjątkowo B), gdyż taki typ budynków jest poszukiwany. Istotny jest również parametr niewynajętej powierzchni biurowej. Wysoka wartość wskaźnika dostępnych powierzchni biurowych może przełożyć się na ceny wynajmu.

Ostatnie 5 czynników z listy wskazanej przez inwestorów zagranicznych to czynniki miękkie. Nie sa to determinanty, ale stanowią potwierdzenie tezy, wskazali już ją Willem Molle i Atze Verkennis ${ }^{19}$, że systematycznie rośnie znaczenie niekosztowych dla przedsiębiorstw czynników lokalizacji. W końcowej fazie wyboru mogą mieć one decydujące znaczenie. W analizowanym przypadku sa to: 1) oferta przygotowana przez JST dla potencjalnych inwestorów (3,33 pkt); 2) promocja miasta (3,27 pkt); 3) jakość obsługi administracyjnej JST (3,20 pkt); 4) mentalność społeczeństwa (3,10 pkt); 5) obecność podobnych podmiotów działających na rynku (3,03 pkt).

W przypadku ofert JST warto zauważyć, że jeżeli oferta dotycząca zachęt lokalizacyjnych została dla inwestora przygotowana profesjonalnie, to czynnik ten jest wysoko pozycjonowany. Jeżeli oferta nie została przedstawiona wcale, respondenci wymieniali go jako jeden z najmniej istotnych. Samo przygotowanie i przedstawienie ofert również ma dwa aspekty: 1) wymierne korzyści wynikajace z konsekwencji realizacji zaproponowanych udogodnień (np. opłacenie szkoleń dla zatrudnianych pracowników centrum, czasowa partycypacja w kosztach najmu powierzchni biurowej); 2) aspekt wizerunkowy związany z jakościa, prestiżem przedstawianej oferty.

Promocja i kreowanie dobrego wizerunku miasta sa wykorzystywane zarówno w przypadku, kiedy inwestor samodzielnie poszukuje lokalizacji, jak i przez doradców podpierających się zestawieniami rankingów atrakcyjności przy konstruowaniu propozycji lokalizacyjnych. Mimo że na listę czynników atrakcyjności gmin składa się wiele elementów (np. potencjał rynku, kapitału ludzkiego, liczba szpitali, przedszkoli, szkół itp.) respondenci jednoznacznie wskazują tutaj rolę JST jako podmiotu stymulującego ten obszar. Znaczenie może mieć samo analizowanie i przekazywanie społeczeństwu informacji o liczbie i sprawności obiektów użyteczności publicznej, jak również sprawność pozyskiwania środków na te cele.

Jakość, sprawność, fachowość obsługi administracyjnej JST to kolejna cecha związana z relacjami JST - inwestor (lub doradcy działający w imieniu inwestora). Dotyczy dwóch momentów czasowych: obsługi w trakcie procedury lokalizacyjnej oraz po zasiedleniu, tj. w czasie prowadzenia działalności gospodarczej. Inwestorzy zazwyczaj wyrabiają sobie opinię na temat omawianej cechy głównie na podstawie drugiego z ujęć czasowych, zbierając informacje o jakości obsługi administracyjnej przez grupę doradców. Natomiast współpraca w trakcie samego wyboru lokalizacji jest działaniem, które ostatecznie może wzmocnić postrzeganie miasta.

Mentalność lokalnej społeczności stanowi swoisty czynnik społeczno-kulturowy wynikający ze świadomości społeczności zamieszkującej dany obszar, jej nastawienia do nowych inwestycji, aktywności i poziomu

${ }^{19} \mathrm{~W}$. Molle, A. Verkennis, Regional development and changing location factors: a challenge for regional and local authorities, „European Journal of Regional Development” 1995, nr 2. 
przedsiębiorczości, aspiracji, poziomu wykształcenia i kultury. Czynnik ten tworzą też wielkość i struktura konsumpcji oraz sytuacja na rynku pracy. Takie uwarunkowania sprawiaja, że lepiej akceptują ten rodzaj branży grupy społeczne o „elastycznym” sposobie myślenia i życia. Również samo podejście do branży outsourcingowej często związane jest z dyskusją o tym zjawisku. $\mathrm{Z}$ jednej strony można postrzegać ją jako powodującą redukcję zatrudnienia, niestabilność miejsc pracy. Z drugiej - delokalizacja łańcucha wartości przedsiębiorstwa sprawia, że taki potencjał można pozyskać, co może przynieść miastu wartość dodaną w postaci np. nowych miejsc pracy czy zwiększonych wpływów do budżetu z tytułu podatków. Świadomość inwestorów, że w danym mieście sa dobrze postrzegani i oczekiwani, jest czynnikiem zainteresowania lokalizacja.

Obecność podobnych podmiotów działajacych na rynku jest czynnikiem opartym m.in. na behawioralnych aspektach procesu podejmowania decyzji i związanym z twierdzeniem Roberta Shillera ${ }^{20}$, że gospodarką w coraz większym stopniu rządzą wrażenia, emocje i owczy pęd, a w coraz mniejszym tzw. przesłanki racjonalne. Na decydenta, jak i na proces decyzyjny wpływa bardzo wiele czynników, w związku z tym nie kierują się oni wyłącznie racjonalnościa w sensie optymalizacyjnym. Poszukuja oni pewnej zbiorowej wiedzy, charakterystycznej dla danej branży czy grupy podmiotów obsługujących klientów o podobnych cechach. Obecność podobnych podmiotów działających na danym rynku zwiększa bezpieczeństwo działania podmiotu, wywołuje też korzyści zewnętrzne. Skupiska podobnych podmiotów (klastry) powoduja, że rynek dostawców, z uwagi na większe ilości usług, oferuje bardziej konkurencyjne ceny, a usługi są dostosowane do określonych wymagań centrów.

\section{PODSUMOWANIE}

Ostatnia dekada przyniosła w Polsce dynamiczny rozwój sektora nowoczesnych usług biznesowych. Jest to z jednej strony efekt uwarunkowanych globalnie zmian w zarządzaniu przedsiębiorstwami i zmian technologicznych, z drugiej - szerokie otwarcie polskiej gospodarki po akcesji do UE. W jego konsekwencji stworzono ponad 150 tys. nowych miejsc pracy, a sam sektor wpływa pozytywnie na inne dziedziny gospodarki, w szczególności na rynek nieruchomości.

W Polsce sektor ten jest zdominowany przez firmy z udziałem kapitału zagranicznego (81\%), które charakteryzuje duża mobilność. Zagraniczni inwestorzy centrów outsourcingu mają sprecyzowane wymagania lokalizacyjne odnośnie do warunków, które musi spełnić dane miejsce. Potwierdziło to również przeprowadzone badanie, w którym poddano analizie zbiór 24 czynników lokalizacyjnych - potencjalnie istotnych $\mathrm{w}$ procesie wyboru miejsca prowadzenia centrum. W procedurze badawczej zredukowano ten zbiór do grupy 13 istotnych, z których 2 można uznać wręcz za determinanty. W zbiorze 8 naj-

${ }^{20}$ R. Shiller, Zwierzęca natura rynku, „Polityka - Niezbędnik Inteligenta Plus” 2012, nr 1. 
wyższych rangą czynników dominuja, czynniki twarde (kosztowe), co potwierdza powszechnie znaną tezę o ich znaczeniu. Zauważalna jest również rosnąca rola czynników miękkich (niekosztowych dla przedsiębiorstw).

Polskę obecnie charakteryzuje wysoka konkurencyjność analizowanej branży, wynikająca z zasobnego rynku wykształconych pracowników i stosunkowo niskich kosztów pracy. Cały czas przewagą Polski pozostaje też jej stabilność polityczna i gospodarcza, bliskość kulturowa z państwami Zachodu oraz bardzo korzystne położenie geograficzne. Warto jednak zwrócić uwagę na słabnąca konkurencyjność Polski w zakresie kosztów pracy. Rodzi to potencjalne zagrożenie migracji przedsiębiorstw w nieodległej perspektywie do tańszych lokalizacji. Należy jednak zwrócić uwagę, że uznawany za podstawowy motyw outsourcingu i delokalizacji - obniżanie kosztów pracy stał się, w opinii inwestorów, motywem drugorzędnym wobec podaży wykwalifikowanych pracowników. Pozwala to sądzić, że utrzymaniu i tworzeniu nowych centrów usług będą sprzyjać działania dla przedsiębiorców majace na celu poprawę warunków funkcjonowania oraz atrakcyjne zachęty inwestycyjne dla nowych inwestorów. Oczywiście dużo zależy też od sytuacji makroekonomicznej i politycznej na świecie. Na koniec warto podkreślić, że wyodrębniony zbiór czynników i ich ranga sa zmienne w czasie, więc powinny być stale monitorowane, jeżeli miasta chca aktywnie pozyskiwać nowych inwestorów.

dr hab. Waldemar W. Budner

Profesor Uniwersytetu Ekonomicznego w Poznaniu

w.budner@ue.poznan.pl

dr inż. Artur Resmer

artur.resmer@gmail.com

\title{
LOCATION MOTIVES FOR OUTSOURCING CENTRES TO CITIES IN POLAND
}

\author{
Summary
}

Modern business services constitute one of the most dynamic developing branches in the economy. This is especially true in Poland. In the last dozen or so years in several Polish cities offering specific location factors over 500 outsourcing service centres have started up. Together they employ over 150 thousand people (in 2015). Intense economic links within these cities have been leading to the establishment of yet more service centres. This branch has been a driving force in the modern office estate market. The article highlights the issue of location choice for outsourcing centres in Poland. Taking into consideration the high dynamics of development of this based on the knowledge economy sector, this issue may be important for business investors, local government units, as well as local business entities. The authors attempt to identify the factors which influence the decisions of managers choosing the place for this activity. A nationwide empirical study was conducted using standardised questionnaire interview addressed to decision-makers in the processes of choosing a location for such centres. The results of these studies include the list of location factors specifying the gradation of their significance to investors when deciding about location. 